JOANNA POPIELSKA-GRZYBOWSKA

Department of Ancient Egyptian and Near

East Cultures, Institute of Mediterranean and

Oriental Cultures,Polish Academy of Sciences

Warsaw, Poland

E-mail: joannapopielskag@hotmail.com
902:001.92(475)”2004/...”

COBISS.SR-ID 254101004

Original research article

Received: November 15th 2016

Accepted: October 31st 2017

\title{
IS IT POSSIBLE TO DEVELOP AND MAINTAIN ARCHAEOLOGICAL AWARENESS AND KNOWLEDGE IN A SMALL TOWN IN POLAND?
}

\begin{abstract}
The author of the paper aims at demonstrating her endeavours to spark interest in ancient times and cultures of the world in a small town in Poland, namely Puttusk - her hometown. Although there is a university in Pultusk, it is still quite difficult incite people's curiosity. We live in such times that time is money and for parents more important are languages and fortunately still physical education as well, but much more rarely knowledge children can acquire, for instance in the humanities. Notwithstanding all of the difficulties, the present author not only conducts once a year archaeological workshop to celebrate the Children's Day, but also she managed to open the Humanistic University for Children in 2012. This makes a positive example and proves that when one tries hard he/she is inevitably doomed to success. Therefore, this case may be treated as a precedent. The present author hopes very much that in the upcoming years there will be more and more Universities for Children in small towns allowing children from localities lying away of municipal centres to develop their curiosity for the world, their interests and skills.

The following paper, illustrated with very many photos, was presented at the conference held at the Archaeological park of Viminacium from 5th to 8th of October 2012 to which the author was kindly invited. However, it is its revised version.
\end{abstract}

KEYWORDS: ARCHAEOLOGY, POPULARISATION, WORKSHOPS FOR CHILDREN, OPEN LECTURES, ANCIENT HISTORY, SMALL TOWNS IN POLAND.

Archaeology and its heritage currently seem to be of interest to many. Notwithstanding this, however, one can observe fewer students studying the humanities in Poland. Therefore Polish educational programmes are seeing cuts in the number of history teaching hours. It is said this is part of changing the ways in which young people are prepared for the social changes taking place in the world, globalisation and commercialisation.

The present author, as Egyptologist, archaeologist, philologist and above all academic teacher, feels responsible that she should share her and her colleagues' knowledge with the rest of Polish society, with special regard to small Polish towns, in large part because she was born in one of them.

There is a crucial and vivid role to be played by the popularisation of archaeological, cultural and historical heritage and its impact in terms of raising awareness of our archaeological and historical roots. In Poland the situation is more difficult in towns than in cities. In Pultusk, the hometown of this author, however, it is more promising because of its Alma Mater Studiorum: Pułtusk Academy of Humanities.

Since 2004 this author has been making efforts to popularise scholarly knowledge among the inhabitants of Pultusk. A range of activities aimed at involving various age groups in the town have 


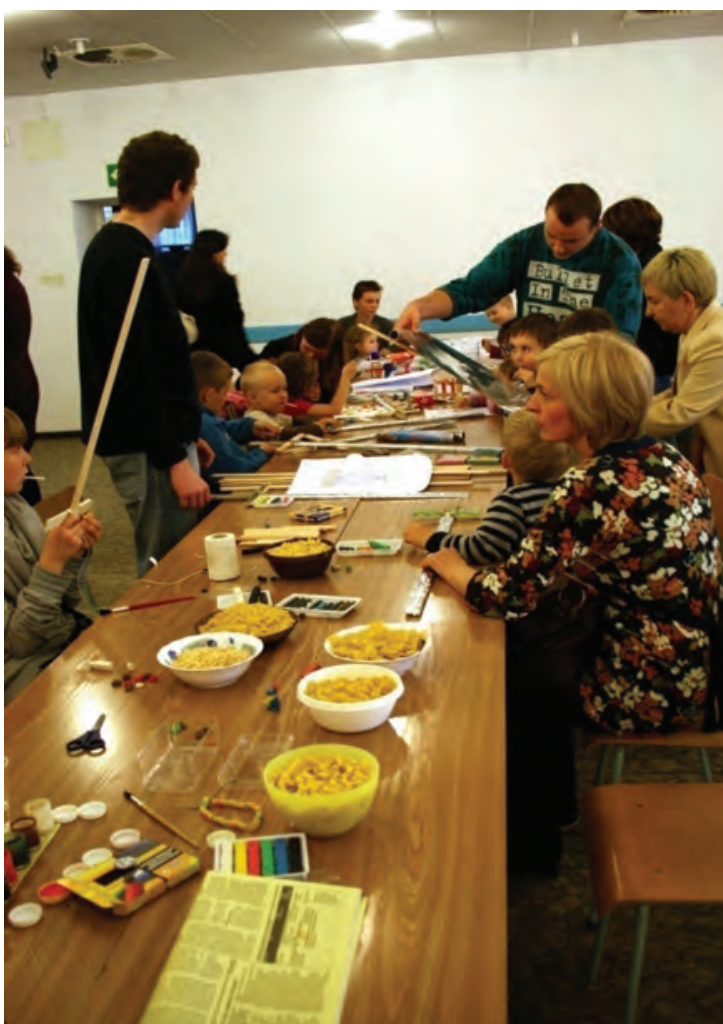

Archaeological workshop for children, June 2010, Archives of the Pultusk Academy of Humanities.

been organised. The usually good atmosphere and the ready help of many people involved let us carry out such organisational endeavours. While difficulties have also been encountered, the organisational work is done and solutions to problems found. Above all, the collaboration of Joanna Popielska-Grzybowska with her students, whose assistance is truly invaluable, is of great importance. Furthermore, we always seek ways to collaborate with the local authorities and in particular the local media (newspapers and TV) to promote these events.

Therefore, from the very beginning we have had contacts with the media both to advertise and promote our activities. Articles appear before and after the planned events. We are co-operating with local newspapers and in particular with Lech Chybowski and Izabela Mierzejewska-Koba. Most of the events are filmed by our colleague, Pawer Kiela (head of multimedia service at the Pultusk Academy of Humanities).

When bigger events are conducted informa-

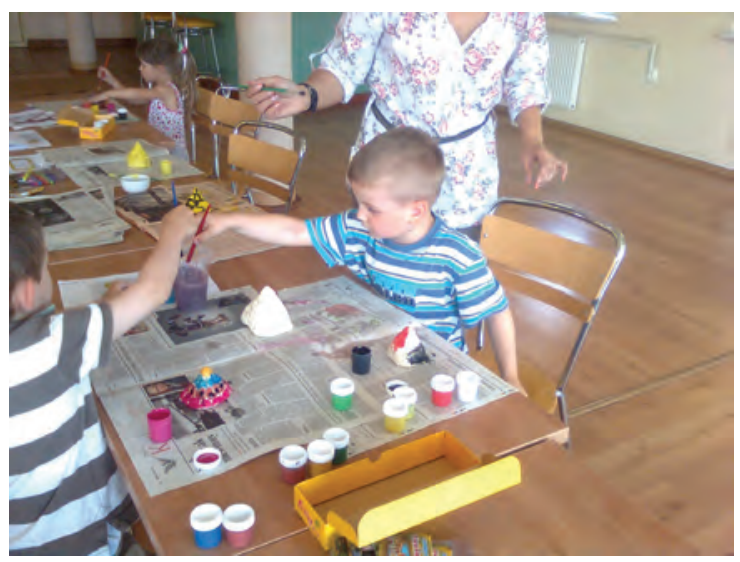

Archaeological workshop for children, June 2011, Archives of the Pultusk Academy of Humanities.

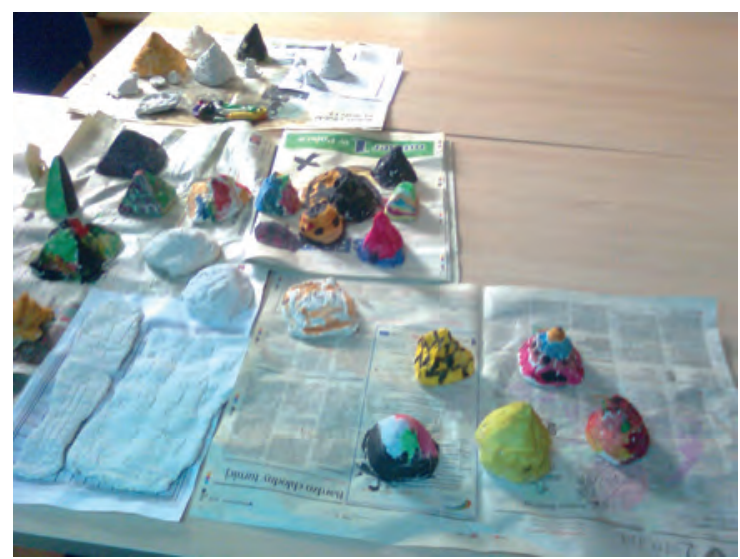

Archaeological workshop for children, June 2011, Archives of the Pultusk Academy of Humanities.

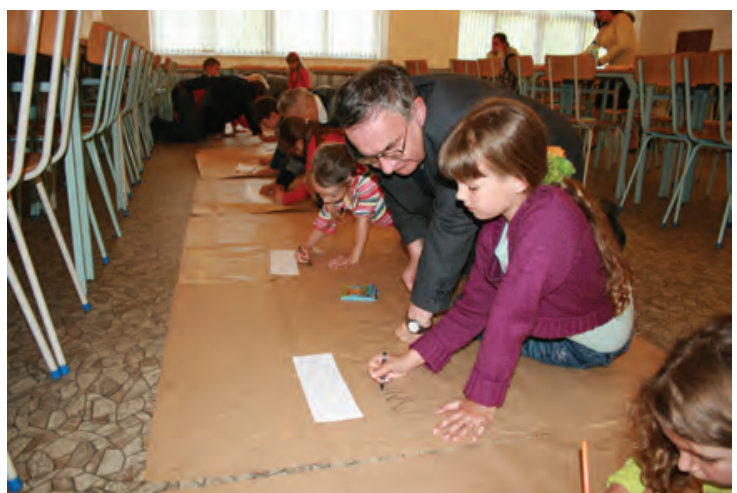

Archaeological workshop for children, June 2012,

Archives of the Pultusk Academy of Humanities.

tion is usually published on the PAP's Science and Scholarship in Poland pages online by Szymon Zdziebłowski (a former student of the author).

As mentioned above, since 2004 varied ventures to popularise archaeology have been organised. These include Polish and foreign discoveries as well as methods of archaeological research. Since then every year on June $1^{\text {st }}$ the present au- 


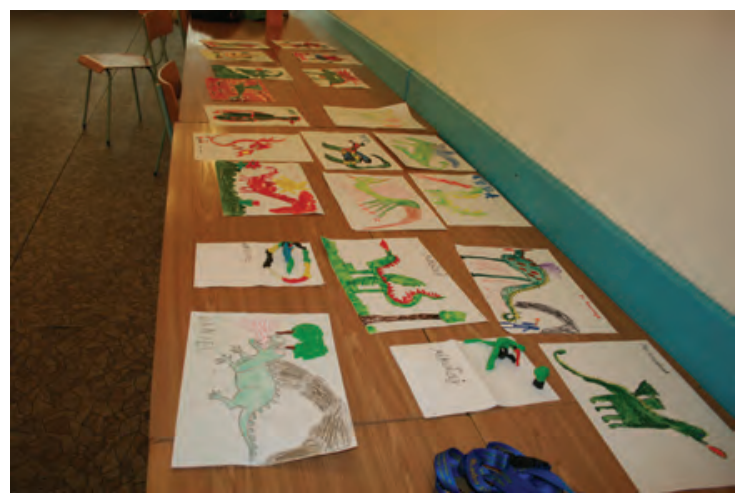

Archaeological workshop for children, June 2012, Archives of the Pultusk Academy of Humanities.

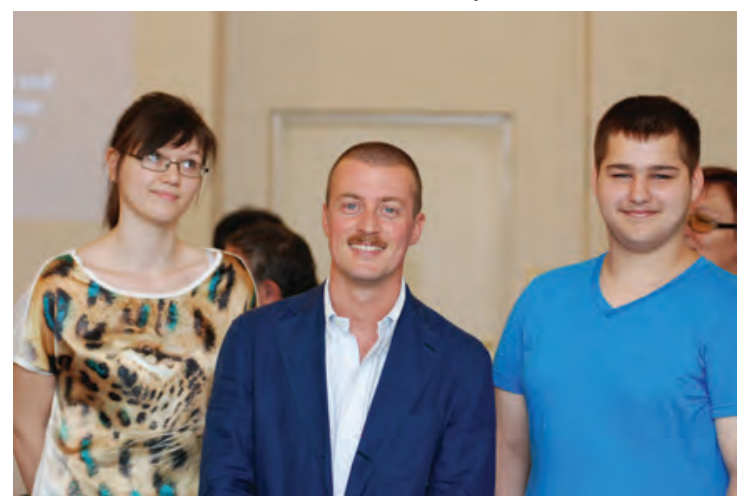

An open lecture on history of Venice, dr Piero Pasini, Ca’ Foscari Univeristy of Venice, and secondary school students, June 2012, photo by dr J. PopielskaGrzybowska.

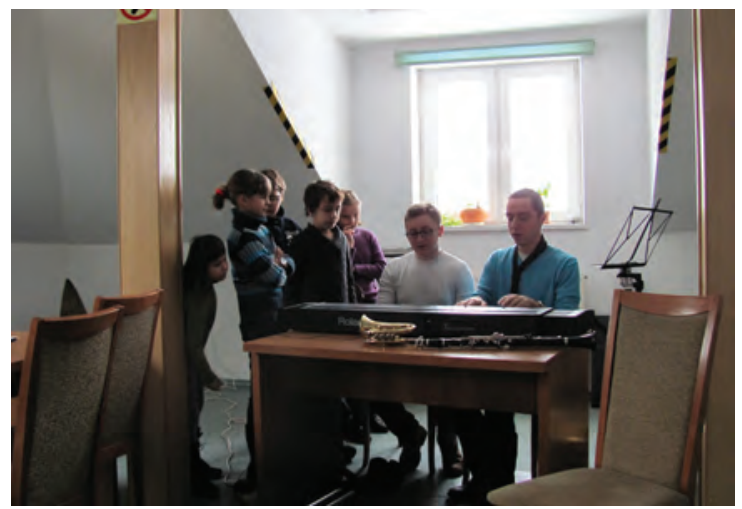

Pultusk Humanistic University for Children, music, 2012, photo by dr J. Popielska-Grzybowska.

thor, with the assistance of her students, conducts archaeological workshops to celebrate Children's Day (Popielska-Grzybowska 2012: 141-143). Various activities in which children are involved are performed. These workshops have already been described in the quoted paper (loc. cit.). The idea also started to help develop a new venture, the University for Children, led by this author who

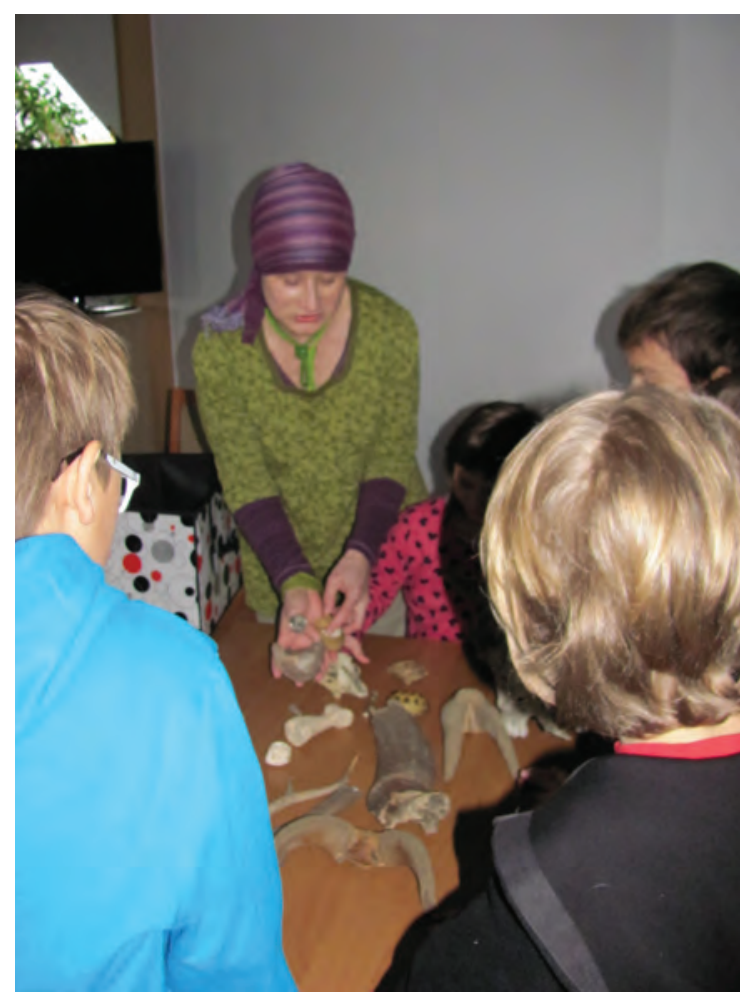

Pultusk Humanistic University for Children, archaeozoology, dr Urszula Iwaszczuk, 2012, photo by dr J. Popielska-Grzybowska.

was assisted by Wioleta Michałowska in the academic year 2012/2013 and since 2014 she has been supported by Joanna Rosińska. Every two weeks children aged from 3 to 11 meet at the Pultusk Academy of Humanities to take part in chatty lessons combined with workshops designed for them. Different, times and various cultures from all over the world are the topics of our meetings. Many and varied, mental as well as manual, activities are performed, both for children and with them.

We support and intersperse our talks and workshops with books, posters, board games, jigsaw puzzles, some fake artefacts and real artefacts as well. We often use PowerPoint presentations to illustrate the topic presented to children to make it easier for them to imagine and feel what life was like in ancient times or is in other countries. Often guests, specialists in a given area of knowledge, are invited, for instance an archeozoologist (Dr. Urszula Iwaszczuk), artists, painters (Barbara Popielska) or musicians. 


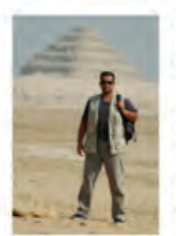

Dr Andrze) Ćwiek, esiptolog Absolwent archeologil srodziemnomonskiej na Unimerynecie Warszowskim

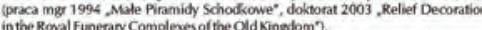
Od 2001 kurator Galerii Egipskiei w Muzeum Archeologicanym

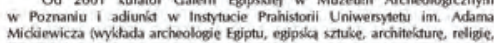

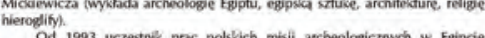

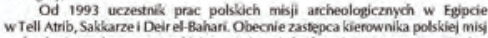
archeologiczno-konsenvatorskiei w Swiatyni kroblowei Hasscepsut w Deiret

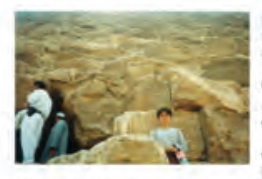

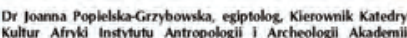
Humanistyczee im. Aleksandra Glepsztora

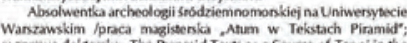

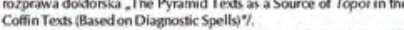
Absolwentka Podyplomowego Studium Humanistycznego
w. lnsthude Badan Uterackich Polkkiej Akademii Nauk (prof

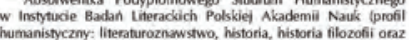

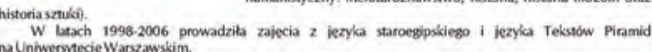
humanistyczny: literaturoznowstwo, historia, historia filozofii oraz na Uninvershtecie Warzzawskim.

Od roku 2004 pracuje, poczankowo jako assstent, obecnie jako adiunla w Akademii Humanistycznej Im. Aleksanda Giesztora w Puttusku, gdzie prowadzi zajecia z archeologi Egiptu i krajow basenu Morz

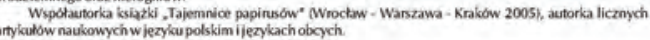

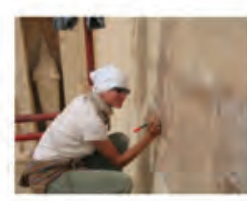

ladwiga Iwaszcruk, archeolog Egiptu

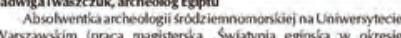

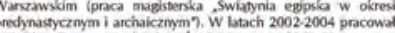
wPolskim Centrum Archeologis Środziemnomonskiej w Kairze. Od roku 2007 pracuje jako asystent w Zaktadzie Ancheologi

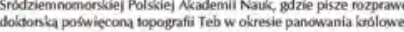

Od roku 1999 uczestnicy w badaniach na terenie Egjptu, jest tahm calonkiem polksiei misyi archeodogiczno konserwatorscie w pracach misji polskoegipskiej w Peluzium. Wspotpracowata tówneez z misja zenerykanska Giza Platea Mapping Project

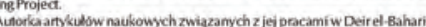

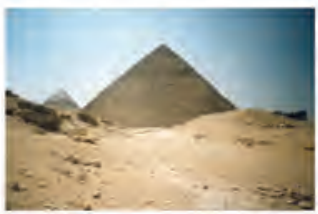

\section{KOD PIRAMID}

Zaszyirowany przekaz od kosmitow, pomnilk przybyszów z Atlantydy, Biblta wykuta w kamienäu, starozyme centra lecanicze, bron masowego razental o piramidach syxrymy prawie codzienníe. Wspóhnym mianownikiem filmow, ksizzek, artykutow i intemetowych newsów sa tyuly. ,Tajemnice píramid", Zagadka Wielkiej Piramidy", _Niezwykla energia

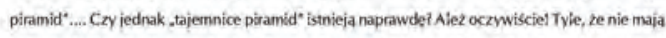
nic wspóbinego z kosmitami. I najważnięszą kwestią nie jest wcake to, jak Egipcjanie zwalili na kupe te millony kamiennych bloków. Wbrew synikajigcemu z ntewtedizy - przekonantu zwolennikow iluzit, wiedza egiptologiczna na temat piramid jest nie tyiko rozlegh, ale 1 fascynujaca. Piramidy a wasctwie zespoly architeltonicze. w ktorych pramidy stanowily centrainy ejemem. nte byly po prostu grobowcams, w kaxdym razte

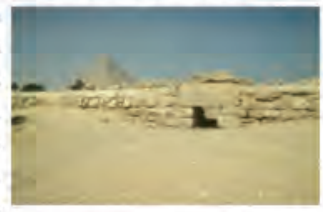
nie w dzisiejszym znaczeniu tego stowa. Kazdy z nich mial być zarazem Resurrection Machine

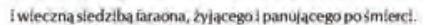

Coym byly i co tak naprawde wiemy o tym kto, kiedy, jak t po co wybudowal ptramidy? Sprobuiny ocklodowat zaszy frowany przekaz starozytrmych budowli..

\section{HATSZEPSUT. KOBIETA-FARAONIJEI „POLSKA"SWWIATYNIA W DEIR EL-BAHARI}

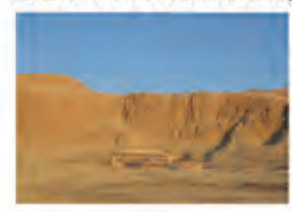

Fasçnujące dzieje królowej, która jako jedn zniewielu kobiet whistorit Egiptu odwazyla się zasiąs na tronie Horusa, zapisane sa dostownie i w przenóini-na kamieniach świątyñ̂ w Deỉr el-Bahari, jej ssiedziby milionów lat" na zachodnim brzegu Teb. Watki tomantyczne zderzala sie tu $z$ najpowazntesscym:

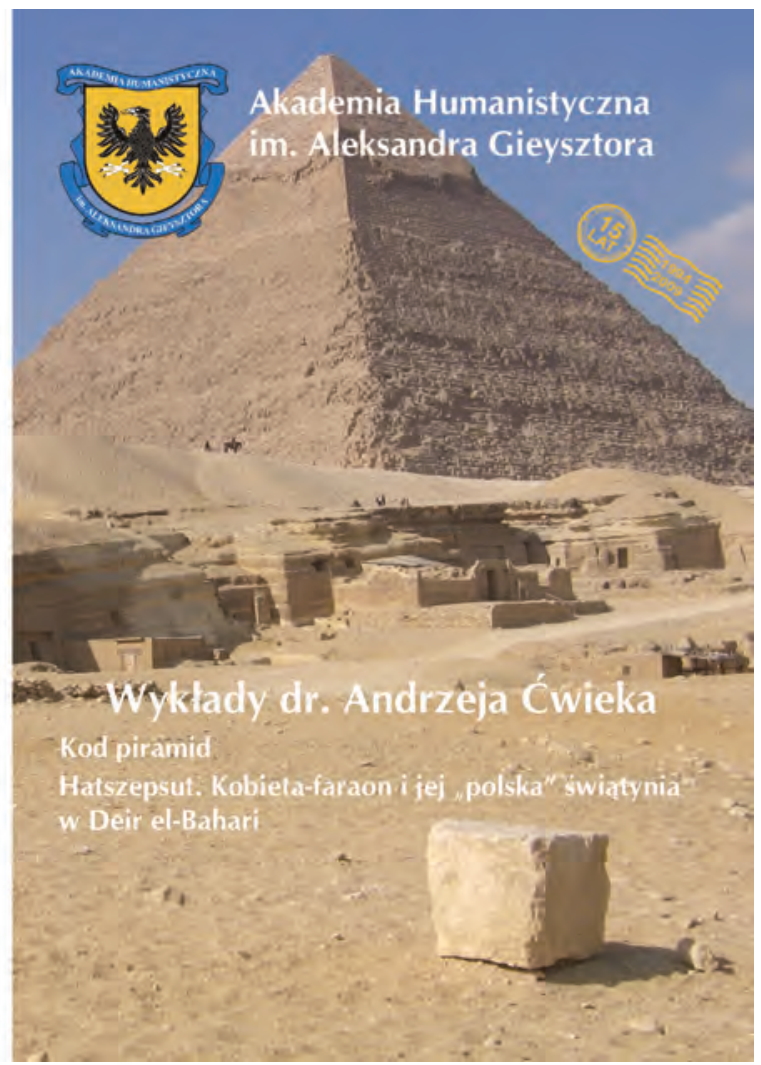

kwestiami egipskiej religii i ideologii wladzy- Legenda a jef boskim pochodzeniu, tajemnica dostojnika Senenmuta, wychowawcy ici corki i domniemanego kochanka, kwestie pozycii Totmesi

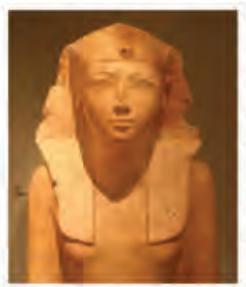

III, przez dwadziescia lat odsuwanego na drugi plan (choc iormalnje wspolizadzacego $z$ Hatszepsuni), i zarzadzonego przez niego pózñiej damnatio memoriae królowej o tym wszystikim mówia mury swlattyni. Niezwykla architekaura : dekoracja tej budowili ujawnia zlożony i gleboki przekaz wiary starozynych $w$ odrodzente faraona po smiercl, stanowiac lednoczesnie narzedzie majace zapewnic Hatszepsut owo wiecrie zycie ipanowante.

Od crterdzlestu sledmlu Lat Swiatynia Hatszepsut stanow: teren prac polskich egiptologów, architektów i konserwatorów.

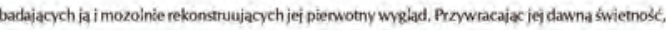
na chwalę wielikiẹ królowei t ku zadowoleniu turystów pobcy specjališci sprawiają, ze swiątynia Haszzepsut jest znowu miejscem magicznym, w pelni zastuguiac na swa starožytna nazwẹ Dzeser

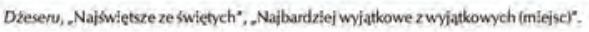

\section{Warszlaty egiptologiczne}

POZNA] TAIEMNICE STAROŻYTNYCH EGIPCJAN (dla dzieci od 6 do 12 lat)

Zapraszamiy dzieci w wieku 6-12 lat na prrygode ze starozytrym Egiptem podczas warszatow antydyczno-lterackich

Warsztaty odbeeda się 1 cerwca $2009 \mathrm{r}$.

w Akademii Humanistyczne im. Aleksandra Gieystiora

przy u’. Daszyniskiego 17 w Pultusku, sala A o godz. 18.30.

Warsztaty poprowadza:

- Drjoanna Popielska-Graybowska

- DrAndrzei Cwiek

- ladwiga lwaszeruk

Dorosłych towarzyszących dzieciom zapraszamy na kawę f clasteczka prosto $z$ Egipti.

An open lecture and workshops on ancient Egypt - materials to promote the event. Text by dr Andrzej Ćwiek, project by dr J. Popielska-Grzybowska and the Bureau of Promotion and Careers of the Pultusk Academy of Humanities. 


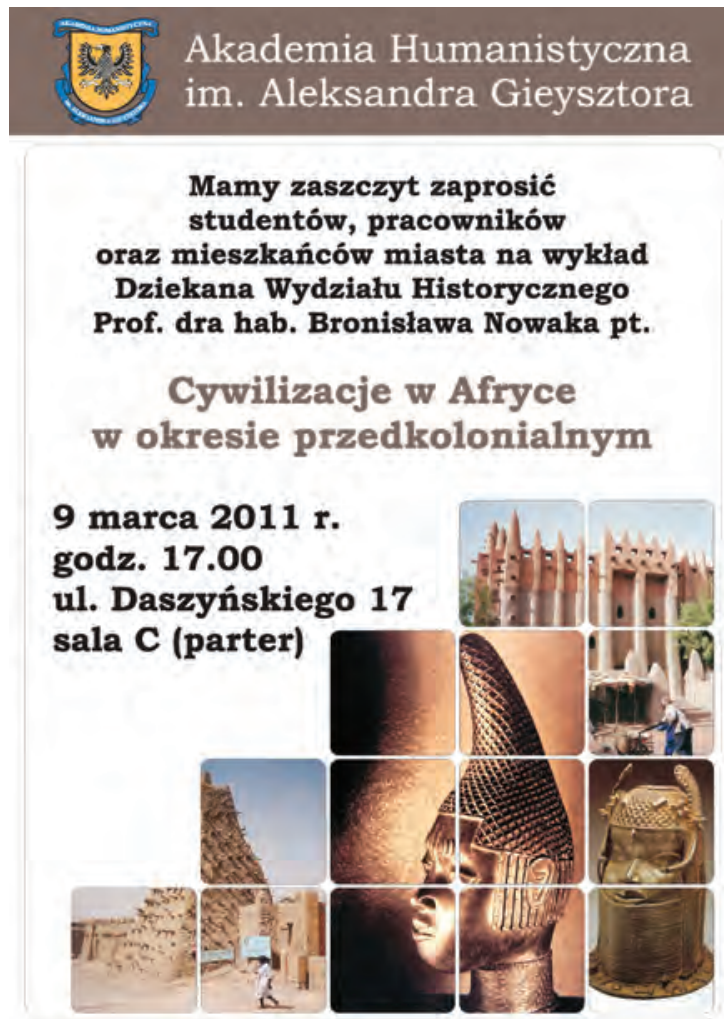

An open lecture on postcolonial Africa by prof. Bronisław Nowak, Archives of the Pultusk Academy of Humanities.

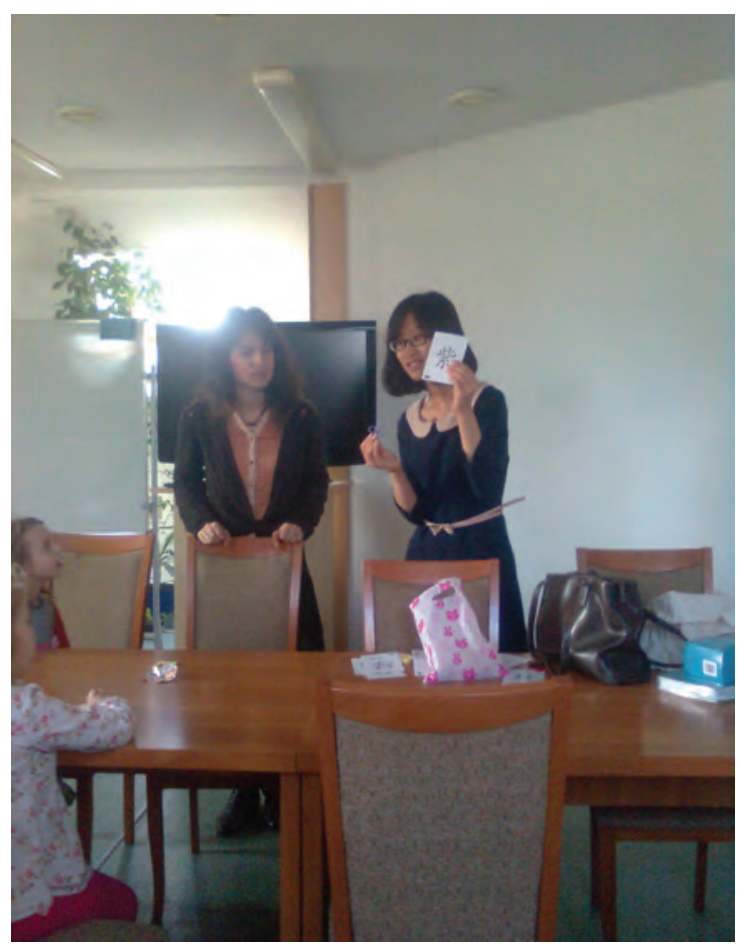

Pultusk Humanistic University for Children, Chinese culture workshop, 2012, photo by J. Grzybowska.

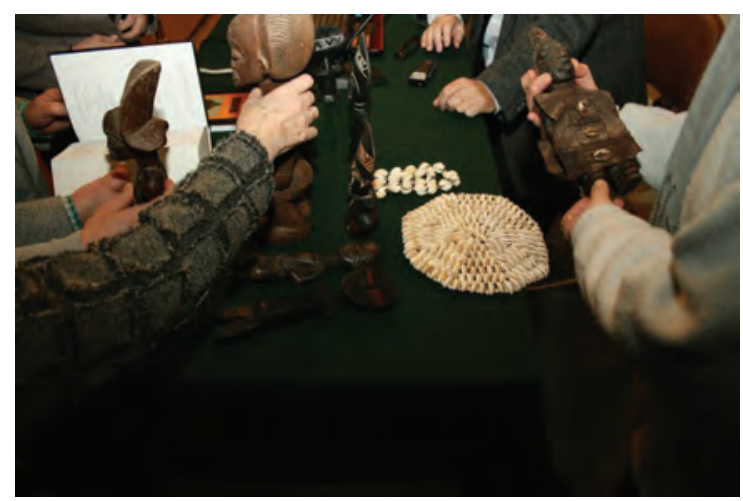

Open lecture on postcolonial Africa by prof. Bronisław Nowak, Archives of the Pultusk Academy of Humanities.

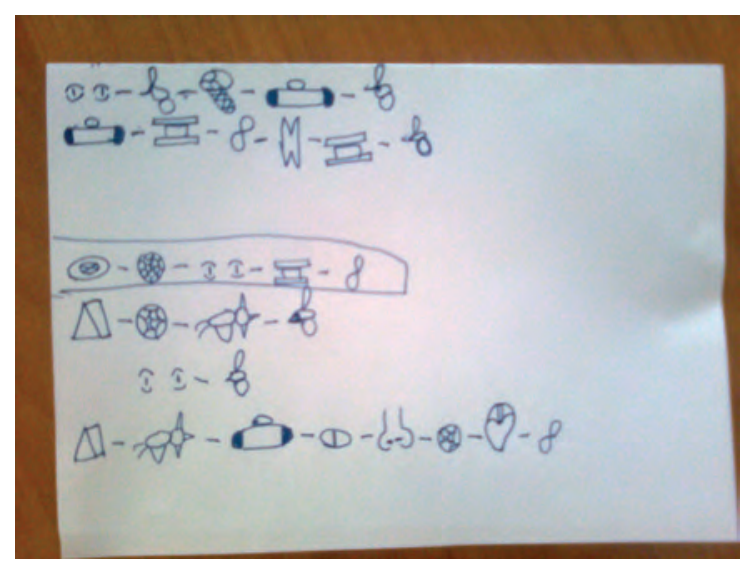

Pultusk University for Children, New writing system invented by one of the students, 2014, photo by J. Grzybowska.

We aim to inform children about all aspects of human culture in an attractive way, demonstrating similarities and differences and thus inspiring kids to discover their own interests, capabilities and talents, stimulating their will to learn and teaching them tolerance. Amusement and group work develops children's social behaviour, teaches cooperation and integrates them with the aim of achieving a collective goal.

Moreover, at the Pultusk Academy of Humanisties there also existed an Archaeological-Anthropological Circle for secondary schools' students.

Over the last six years, and even before the University for Children and Youth Group were opened, students from secondary schools, mainly from the Liceum named after Piotr Skarga, have been coming to the lectures at the Academy. These lectures are above all devoted to ancient history 
and the history of the Vikings, depending on the lecturer, namely her/his scholarly specialisation and the research conducted by them.

Other initiatives are open lectures by Polish and/or foreign scholars. Archaeologists, historians and historians of art come to present their current research to the public, namely to share them with the inhabitants of Pultusk. There have been lectures familiarising people with the cultures and cultural heritage of Ancient Egypt (lectures on Saqqara excavations delivered by prof. Karol Myśliwiec, dr Kamil O. Kuraszkiewicz and Agnieszka Kowalska; on the Giza Plateau Mapping Project by dr Anna Wodzińska; on ancient Egyptian religious texts and beliefs and on ancient Egyptian language and writing by dr Joanna Popielska-Grzybowska; on Egyptian pyramids by $\mathrm{dr}$ Andrzej Ćwiek; on Polish mission and discoveries in the Hatshepsut temple by dr Andrzej Ćwiek and dr Jadwiga Iwaszczuk), Sudan (lectures on archaeological excavations by prof. Mahmoud ElTayeb and Henryk Paner; a lecture on everyday life in contemporary Sudan by prof. Mahmoud ElTayeb), the Near East, Bible studies included (a lecture on archaeology and the Bible by dr Jacek Konik), cultures of different peoples of Africa (a lecture on postcolonial Africa by prof. Bronisław Nowak); cultures and cultural changes in Europe (lectures on the Vikings by prof. Władysław Duczko; a lecture on the history of Venice by $\mathrm{dr}$ Piero Pasini) as well as on cultural heritage of China (prof. Li Qikun). The last under the auspices of prof. Jerzy Gąssowski.

Scholarly and popularising cultural heritage conferences and symposia are also organised.

Since 2012 when the lecture, which had been a base of this paper at the Archaeological Park in Viminacium was delivered, some things have changed for the better. Last October Humanistic University for Children has commenced the fifth year of its existence.

Furthermore, the present author together with many other enthusiasts belongs, as a charter member, to the Society of the Children's Universities

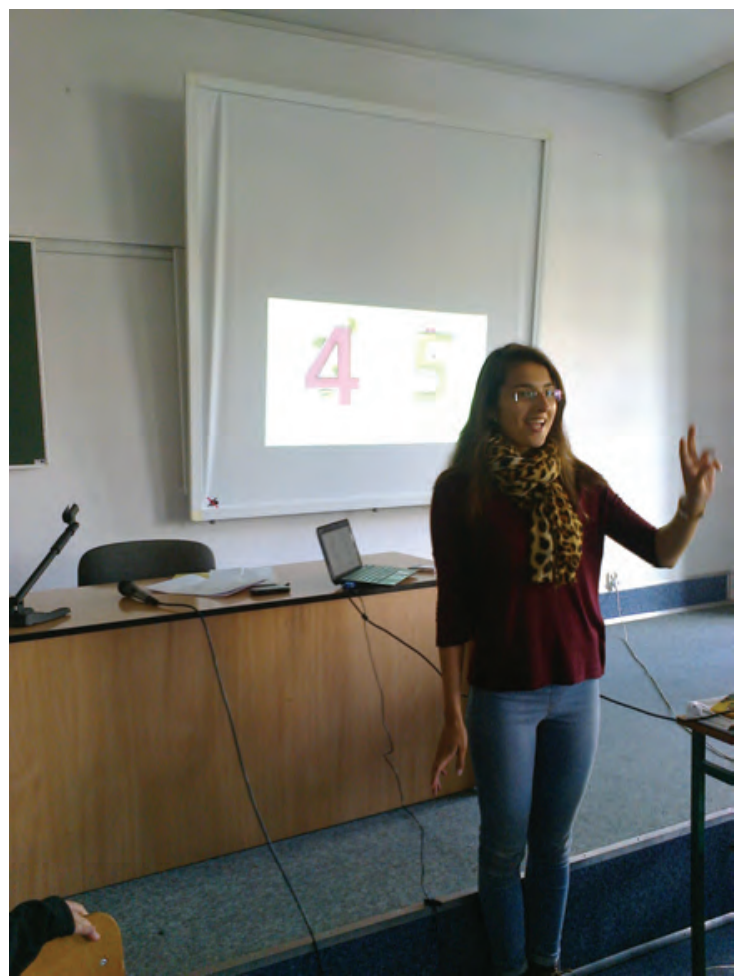

Pultusk University for Children, Portugal - workshop, 2015, photo by J. Popielska-Grzybowska.

created in 2015 with its abode in Warsaw. Added to this, the Humanistic University for Children based at the Puttusk Academy of Humanities was presented at four Congresses of the Children's Universities in Warsaw (http://www.dzieci.edu.pl/).

Joanna Popielska-Grzybowska has also initiated collaboration with the volunteers that come to Poland supported by the Erasmus plus European programme and the FIYE Poland (=Centre of International Youths' Exchange and Volunteering; http://www.fiye.pl/index.php?option=com_content\&view=article\&id=36\&Itemid=18\&lang=pl). The volunteers who come to Pułtusk and Warsaw from all over the world are invited to the Humanistic University for Children to familiarise our young students with their countries, their culture, traditions and languages as well. To date we had the opportunity to talk to the children about the following countries: Portugal, Spain, Russia, Ukraine, Italy, Greece, Finland, Colombia and Brazil, France, Germany, Austria and Turkey. The next planned meeting will be devoted to Italy and Costa Rica. Thanks to availability of the foreign 


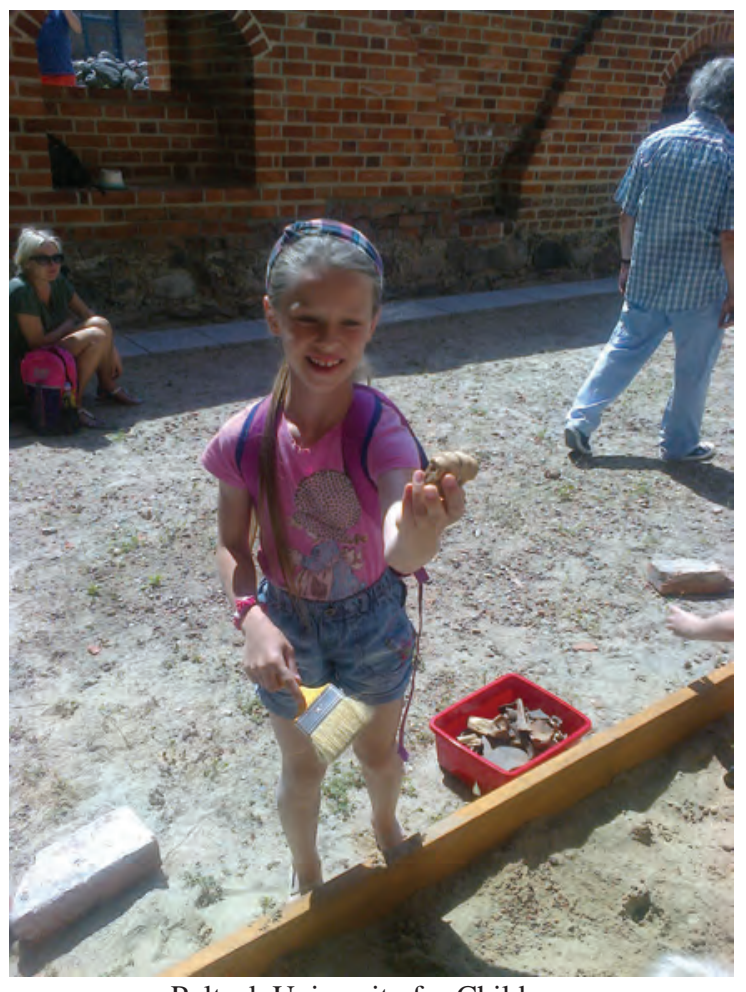

Pultusk University for Children, Archaeological excavations, June 2016, photo by J. Popielska-Grzybowska.

guests and their will to share their knowledge and experiences of different cultures, the children from the Humanistic University for Children from such a small town as Pultusk is (20.000 inhabitants), have an exceptional opportunity to get to know various people even form very remote countries and their cultural heritage.

Consequently our presentations regarding ancient cultures such as: ancient Egypt, ancient Greece and Rome as well as ancient Sumer and all other Near Eastern civilizations and cultures, may become much more aware of the contemporary differences between today's people too. Consequently, we believe and do hope, they become more tolerant and open-minded adults.

Moreover, we invited older children and adolescents to cooperate with us and present their passions to the younger colleagues.

It may be added that the children receive student record books and at the end of each year of education diplomas.

Furthermore, we have created two web sites of our University. One on Facebook (https:// pl-pl.facebook.com/Humanistyczny-Uniwersytet-dla-Dzieci-921603594560721/) and the other one (www.hud.edu.pl). The logo and all illustrations are designed by our young students. The videos promoting our lectures and workshops are filmed by one of the alumni.

In cooperation with the Faculty of Elementary Education of the Pułtusk Academy of Humanities the present author - as a representative of the Transcultural Section of the Scientific Society Educare (http://tneducare.e-kei.pl/?page_id=87) - organised in 2015 the conference "Kreatywne postrzegania świata przez dziecko" (="Child's creative perception of the world") at which our activities were demonstrated to scholars and teachers from Pultusk and the region.

Within the works of the Scientific Society Educare the Humanistic University for Children is displayed and discussed very frequently (http:// tneducare.e-kei.pl/?page_id=42).

Joanna Popielska-Grzybowska has succeed in establishing a cooperation with the Mayor and Vice-Mayor of the town and the Directors of the District Authority Office who support our endeavours, for example by supplying transport for our scholarly excursions, as it occurred last academic year when we went to archaeological excavations led by Izabela Jakubowska in the Castle in Ciechanów.

The present author gives a lot of mini-lectures and chatty-lectures in many Pułtusk kindergardens: Miejskie Przedszkole no 4, Urwis, Malinowe Przedszkole, In 2014/2015 she was invited to conduct a series of workshops in the Miejskie Przedszkole no 4 (=Town Kindergarten no 4). The "lessons" were all devoted to ancient Egypt and archaeologists as well as their work. Moreover, a former student of the Humanistic University for Children wrote a scenario of a play about ancient Egyptian gods and the Kindergarten children guided by the student and their educators prepared a play which was put on the stage at the Pultusk Academy of Humanities (https://www.youtube. 


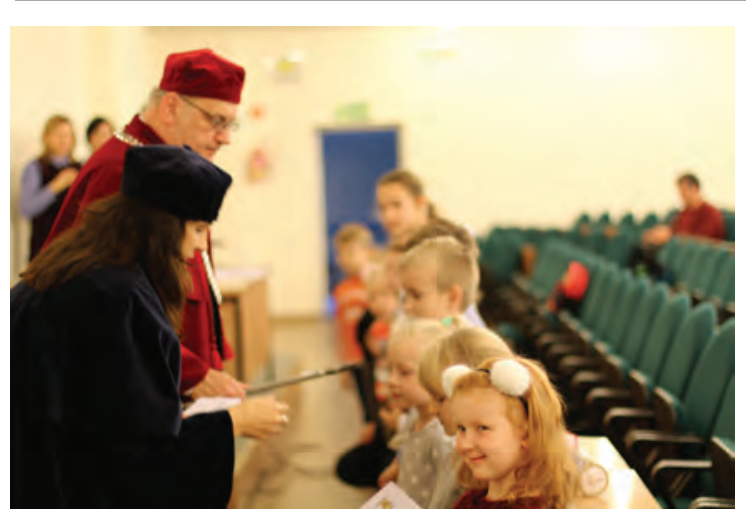

Pultusk Humanistic University for Children. Inauguration of the academic year 2016/2017, Archives of the Pultusk Academy of Humanities.

com/watch?v=k8F-PZ53ST0). It took place as a part of the above-mentioned conference.

Two years ago a collaboration with the Nasielski Children's University (http://europaimy. org/www/pl/aktualnosci/286-v-semestr-nasielskiego-uniwersytetu-dzieciecego) was set up.

The future seems to be very promising as we intend to establish a branch of the Pułtusk Humanistic University for Children in Ciechanów - a bigger town which was the capital of the voivodeship, but now is suffering from lack of captivating educational offers for younger children.

Therefore, as one may observe, we neither resigned nor stopped trying and making more and more efforts to animate and re-animate non-formal education of our young generations in Pultusk and the other towns in its vicinity.

However, as the Humanistic University for Children is based on volunteer work of the coordinator, the assistant and the lecturers and we still do not have our children-friendly, cosy room, the next crucial step is to gain external financing what we are constantly trying to achieve.

It is interesting how these endeavours have impacted the lives of local people. At the very beginning when the above-mentioned events started to be organised not many people attended. At first it seemed local people neither had much interest nor much will to participate in "scholarly" - and thus perhaps boring - meetings. However, every year more and more are coming. When it turned out how interesting and different from other freetime activities they were, people began to come and bring their children and friends along to gain some knowledge and to have some fun as well.

Notwithstanding all the financial problems that appear when organising workshops, chatty talks, lectures or conferences, what we do brings a lot of pleasure and satisfaction from a well done job and the smiles on participants' faces make up for every single effort.

All in all, although it may sometimes be difficult to develop and maintain archaeological and cultural awareness and knowledge among the inhabitants of a small town in Poland, it is possible to do so and thus the question formulated in the title of this paper can be answered in the affirmative.

\section{BIBLIOGRAPHY}

Congresses of the Children's Universities in Warsaw: http://www.dzieci.edu.pl/ /accessed 04.11.16/

FIYE Poland (=Centre of International Youths' Exchange and Volunteering; http://www.fiye. pl/index.php?option=com_content\&view=article\&id=36\&Itemid=18\&lang=pl /accessed 04.11.16/

Pultusk Humanistic University for Children: www.hud.edu.pl /accessed 04.11.16/ https://pl-pl.facebook.com/Humanistyczny-Uniwersytet-dla-Dzieci-921603594560721/ /accessed 04.11.16/

Nasileski Uniwersytet Dziecięcy: http://europaimy.org/www/pl/aktualnosci/286-v-semestr-nasielskiego-uniwersytetu-dzieciecego /accessed 04.11.16/

Film: Play „Czy wydawało Wam sie kiedyś, że... tu byliście?" : https://www.youtube.com/ watch?v=k8F-PZ53ST0 

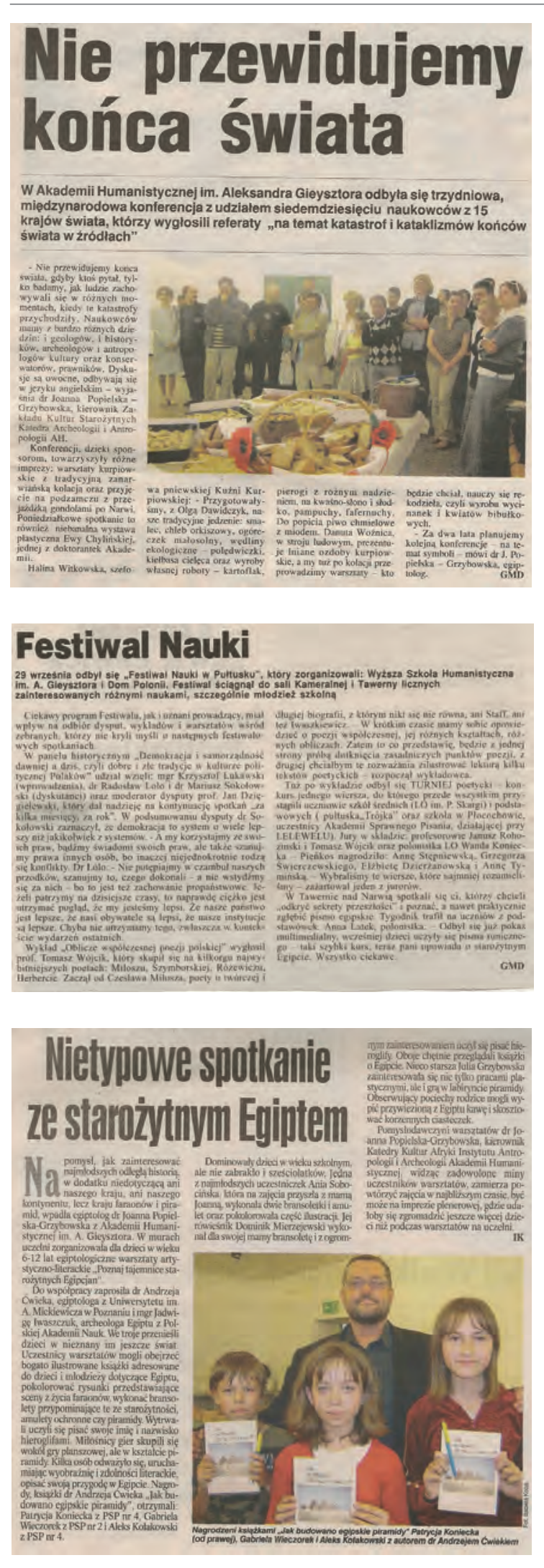

Samples of articles about archaeological and historical events published in local newspapers.
Popielska-Grzybowska, J., 2012

Archaeological workshops to celebrate Children's Day, in: R. Chowaniec, W. Więckowski (eds), Archaeological Heritage - Methods of Education and Popularisation, British Archaeological Reports, Oxford 2012, p. 141-143.

Popielska-Grzybowska, J., 2016

Humanistyczny Uniwersytet dla Dzieci współczesny model kształcenia, [e-book] $\mathrm{Hu}$ manistyczny model kształcenia, M. Szymańska, A. Lasota (eds.), Towarzystwo Naukowe Educare Online Publications (http://tneducare.e-kei. pl/?page_id=42; /accessed 04.11.16/)

Popielska-Grzybowska, J., 2016

Nauczanie o starożytnym Egipcie - dawniej i dziś na Uniwersytetach Dziecięcych oraz Uniwersytetach III wieku w Pułtusku i innych miastach regionu, S.J. Pastuszka i J. Sztejnbis-Zdyb (eds), Państwo - demokracja - chłopi. Studia z historii społeczno-politycznej Polski (XVII-XX w.) Ksiega Jubileuszowa profesora zw. dr hab. Romualda Turkowskiego, Wydawnictwo Muzeum Historii Polskiego Ruchu Ludowego, Warszawa - Kielce - Pułtusk 2016, s. 495-504.

Transcultural Section of the Scientific Society Educare: http://tneducare.e-kei.pl/?page_id=87 / accessed 04.11.16/ 


\section{REZIME \\ DA LI JE MOGUĆE PODSTAĆI I OČUVATI ZNANJE I SVEST O ZNAČAJU ARHEOLOGIJE U MALOM GRADU U POLJSKOJ?}

KLJUČNE REČI: ARHEOLOGIJA, POPULA-

RIZACIJA, RADONICE ZA DECU, OTVORENA PREDAVANJA, DREVNA ISTORIJA, MALI GRADOVI U POLJSKOJ.

U današnje vreme čini se da su mnogima zanimljivi arheologija i njena zaostavština.

Bez obzira na to, primećuje se da je u Poljskoj sve manje studenata humanističkih nauka, pa se iz tog razloga u poljskim obrazovnim programima predviđa smanjenje broja sati za nastavu iz istorije. Smatra se da se i time vrši promena načina na koji se mladi spremaju za društvene promene koje se odvijaju u svetu, globalizaciju i komercijalizaciju.
Autorka, kao egiptolog, arheolog, filolog, a pre svega akademski profesor, smatra da ima odgovornost da svoje znanje i znanje svojih kolega podeli sa javnošću u Poljskoj, s posebnim osvrtom na male poljske gradove, pre svega zbog toga što je rođena u jednom od njih. Potrebno je odigrati presudnu i snažnu ulogu u popularizaciji arheološke i istorijske baštine koja će uticati na podizanje svesti o našim arheološkim i istorijskim korenima. Od 2004. godine ova autorka pokušava da popularizuje naučna saznanja stanovnicima Pultuska. Organizovano je niz aktivnosti usmerenih na uključivanje različitih starosnih grupa u gradu. Organizuju se otvorena predavanja, konferencije i simpozijumi na kojima se kulturna baština predstavlja na naučan i popularan način. Svi naši napori pokazuju da je organizovanje takvih događaja u Pultusku, jednom od poljskih gradića, veoma ohrabrujuće. 